\title{
Analysis of Judicial Precedents Cases Regarding Skin Cancer from 1997 to 2017 in Republic of Korea
}

\author{
Su Hwan Shin ${ }^{1,2}$, Won Lee ${ }^{3,4}$, So Yoon $\mathrm{Kim}^{3,4}$, Gwanghyun Jo ${ }^{5}$, Je-Ho Mun ${ }^{5}$, Soo Ick Cho ${ }^{5}$ \\ ${ }^{1}$ Doctoral Program in Medical Law and Ethics, Yonsei University, ${ }^{2}$ Blue Urology Clinic, ${ }^{3}$ Division of Medical Law and Bioethics, \\ Department of Medical Humanities and Social Sciences, Yonsei University College of Medicine, ${ }^{4}$ Asian Institute for Bioethics and Health \\ Law, Yonsei University, ${ }^{5}$ Department of Dermatology, Seoul National University College of Medicine, Seoul, Korea
}

Background: Both medical disputes and the incidence of skin cancer are increasing in Korea. Objective: The aim of this study was to figure out the medical litigation related to skin cancer and propose a method to prevent the medical disputes. Methods: Skin cancer-related judgments were searched by The Supreme Court of Korea's Written Judgment Management System based on the keywords for skin cancer. The search system included sentenced cases at the Lower Courts, the Appellate Courts, and the Supreme Court from 1997 to 2017. Results: Seven cases were selected as the litigation cases related to skin cancer. Four cases (57.1\%) presented malignant melanoma, while the rest presented squamous cell carcinoma, metastatic skin cancer, and peripheral T cell lymphoma (1 case in each). Four cases resulted in death from cancer metastasis, and 3 cases presented as sequelae. The legal issues related to the medical disputes could be categorized as follows: misdiagnosis, delayed diagnosis, performance error, and lack of informed consent. Delayed diagnosis and lack of informed consent were the most common issues $(n=4)$ in the precedents. Five cases (71.4\%) were sentenced the awarded amounts to the plaintiff, including 2 cases of settlement decision. The average awarded amount was 42,553,644 $\pm 27,567,455$ Korean won.

Received November 9, 2018, Revised December 13, 2018, Accepted for publication December 19, 2018

Corresponding author: Soo Ick Cho, Department of Dermatology, Seoul National University Hospital, 101 Daehak-ro, Jongno-gu, Seoul 03080, Korea. Tel: 82-2-2072-2412, Fax: 82-2-742-7344, E-mail: chlroe@hotmail.com ORCID: https://orcid.org/0000-0003-3414-9869

This is an Open Access article distributed under the terms of the Creative Commons Attribution Non-Commercial License (http://creativecommons. org/licenses/by-nc/4.0) which permits unrestricted non-commercial use, distribution, and reproduction in any medium, provided the original work is properly cited.

Copyright (c) The Korean Dermatological Association and The Korean Society for Investigative Dermatology
Conclusion: Physicians should pay attention to the cases of the skin cancer to prevent medical malpractice and disputes. The practices pertaining to proper diagnosis, treatment plans, and obtaining an informed consent should be followed during the course of treating skin cancer. (Ann Dermatol 31(3) $300 \sim 306,2019$ )

\section{-Keywords-}

Dermatology, Jurisprudence, Malpractice, Melanoma, Skin neoplasms

\section{INTRODUCTION}

Medical disputes are increasing worldwide. Recently, researches about medical disputes are presenting the viewpoints of the cause of the medical malpractice or the dispute, while deviating from the existing concept that evaluates the liability of doctors and patients with regards to medical accidents ${ }^{1,2}$. In recent years, studies on medical malpractice and conflict prevention by medical litigation analysis in Republic of Korea have been published ${ }^{3-6}$. In dermatology, no paper dealing with specific medical disputes has been reported thus far.

Skin cancer is increasing due to the exposure of ultraviolet radiation by ozone depletion, longer life expectancy, increased early detection rates, and rising public awareness by education ${ }^{7}$. The prevalence of the skin cancer in Korea is relatively low in comparison to the western countries. However, recent epidemiological studies have reported that the incidence of the skin cancer is steadily increasing $^{7-10}$.

Legal issues related to the skin cancers have been relatively low in Korea. However, the prevalence of the skin cancers is increasing, and the legal access to medical liti- 
gation is rising due to changes in the legal environment, hence medico-legal considerations related to the skin cancer are likely to increase in the near future. Therefore, in this study, the authors investigated the litigated cases related to the malignant skin tumors in the past, and then proposed a method to prevent and manage the medical disputes based on the cases discussed to seek the judgment.

\section{MATERIALS AND METHODS}

This research included skin cancer-related civil proceedings sentenced within the courts of Korea from 1997 to 2017.

The researchers selected the precedents pertaining to the compensatory damage from medical malpractice and in which the disputed disease was skin cancer. To collect the case-related decisions, the researchers visited the Special Collections Reading Room with the permission of the Supreme Court Library of Korea. The Supreme Court of Korea's Written Judgment Management System, a searching engine for written judgments, is available at the Special Collections Reading Room. Some skin cancer-related search terms were set to avoid missing any case-related judgments. Considering the common histologic types of the skin cancer, following search terms were included: "skin cancer", "malignant melanoma (MM)", "basal cell carcinoma (BCC)", "squamous cell carcinoma (SCC)", "skin metastasis", "(extramammary) Paget's disease", "mycosis fungoides", "cutaneous lymphoma", "leukemia cutis", "Bowen's disease", "angiosarcoma", "Kaposi's sarcoma", and "dermatofibrosarcoma protuberans".

After searching the related precedents, the researchers requested to review the official copies of the written judgment available with the Lower Courts, the Appellate Courts, and the Supreme Court. The analyzed contents in each litigated case included basic information of the plaintiffs and the defendants, clinical characteristics, and legal issues. The issues of primary disputes were categorized as follows ${ }^{11}$ : Misdiagnosis was defined in the cases presenting failure to suspect the skin cancer at the initial diagnosis; delayed diagnosis was stipulated in the cases that considered the skin cancer as the initial diagnosis, but failed to make the final diagnosis appropriately; performance error was inferred from the cases with improper management even after proper diagnosis.

The detailed analysis of each precedent was performed independently by a dermatologist (Cho SI) for the dermatological issues and by a researching physician (Shin $\mathrm{SH}$ ) for the medical law and ethics. In cases of disagreement between the two authors, the clinical issues were decided af- ter discussing with the other dermatologist (Mun JH), and the legal issues were decided after discussing with the doctor of public health (Lee W).

\section{RESULTS}

\section{Keywords and search results}

After searching, a total of 132 official copies of written judgments were received from each court. The researchers collected the precedents for each search term following the process of deletion of personally identifiable information by the courts ("skin cancer" [10 cases], "MM" [14 cases], "BCC" [0 case], "SCC" [11 cases], "skin metastasis or metastatic skin cancer" [5 cases], "[extramammary] Paget's disease" [2 cases], "mycosis fungoides" [0 case], "cutaneous lymphoma" [8 cases], "leukemia cutis" [78 cases], "Bowen's disease" [0 case], "angiosarcoma" [4 cases], "Kaposi's sarcoma" [0 case], and "dermatofibrosarcoma protuberans" [0 case]). Of the collected case-related judgments, several judgments were excluded, namely, overlapped judgments, rulings mentioned by the search term that were not the issues of litigation, precedents related to the employment injuries, and cases of the carcinomas other than the skin including the mucous membrane. Finally, 7 unique cases were selected that were identified as pertaining to medical malpractice lawsuits regarding skin cancer (Fig. 1).

\section{Analysis of the judicial precedents involving the skin cancer}

Of the total 7 litigated cases, 4 cases were disputed for the MM. SCC, metastatic skin cancer, and peripheral T-cell lymphoma were reported in 1 case each. Disability and complication including death from cancer metastasis were reported in 4 cases, limb amputation in 1 case, mastication and pronunciation disorder in 1 case, and hypogonadism with azoospermia was reported in 1 case (Fig. 2). Of the total 7 cases, 3 cases (42.9\%) were judged in favor of the plaintiff. In 2 cases, the court dismissed the plaintiffs' claims, and the other 2 cases involved the settlement decision. Table 1 shows a detailed clinical summary of each case.

The types of medical institutions included 6 university hospitals and 1 local clinic. All the defendants were legal entities. With regard to the medical specialties that led to the lawsuit, there were mainly the departments performing the medical examination, such as dermatology, dental medicine, rheumatology, general surgery, plastic surgery, and radiation oncology with an exception of the department of pathology dealing with the pathologic specimens. Of the 7 sentenced cases, 4 cases $(57.1 \%)$ were resolved 


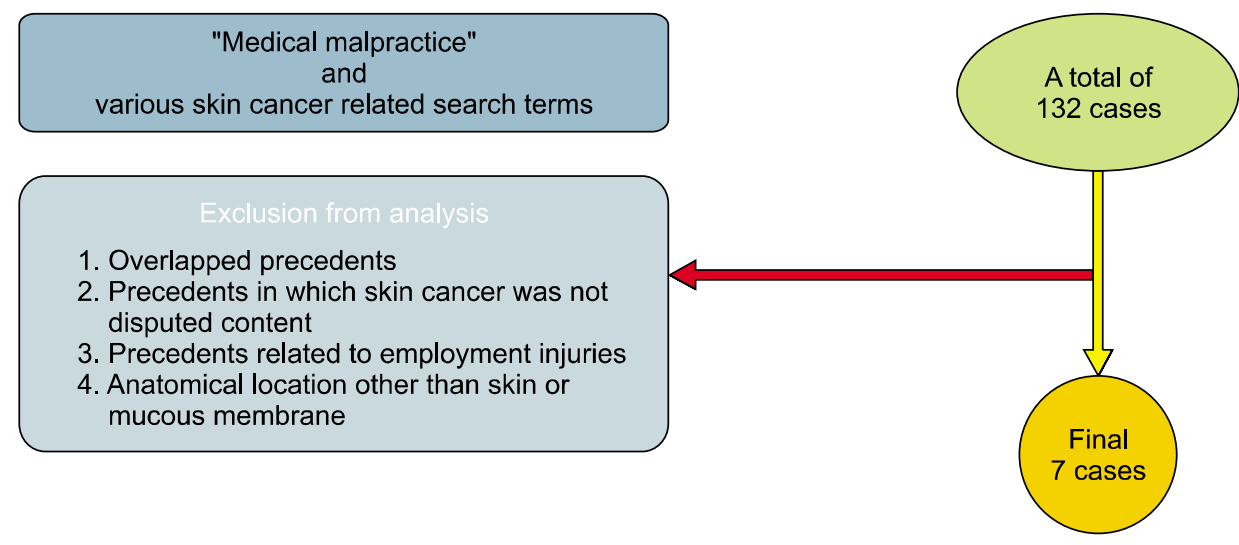

Diagnosis

Metastatic skin cancer $(n=1)$

Malignant melanoma $(n=4)$

Squamous cell carcinoma $(n=1)$

Peripheral T-cell lymphoma $(n=1)$
Complication

Death $(n=4)$

\section{Language disability $(n=1)$}

Limb amputation $(n=1)$

Hypogonadism $(n=1)$
Fig. 1. A total of 7 cases of the judicial precedents were analyzed in this study. The skin cancer related search terms included "skin cancer", "malignant melanoma", "basal cell carcinoma", "squamous cell carcinoma", "skin metastasis", "(extramammary) Paget's disease", "mycosis fungoides", "cutaneous Iymphoma", "leukemia cutis", "Bowen's disease", "angiosarcoma", "Kaposi's sarcoma", and "dermatofibrosarcoma protuberans".
Fig. 2. Diagnosis and complications of the skin cancer in all the 7 cases of the judicial precedents.

Table 1. Clinical summary of the cases pertaining to the judicial precedents regarding the skin cancer

\begin{tabular}{|c|c|c|c|c|c|c|c|}
\hline Case & $\begin{array}{c}\text { Year } \\
\text { (clinical event) }\end{array}$ & $\begin{array}{c}\text { Sex/age } \\
(y r)\end{array}$ & Initial diagnosis & Final diagnosis & $\begin{array}{l}\text { Anatomical } \\
\text { location }\end{array}$ & $\begin{array}{l}\text { Disputed } \\
\text { main issue }\end{array}$ & $\begin{array}{c}\text { Damage/complication } \\
\text { (year) }\end{array}$ \\
\hline$\# 1$ & 2007 & $\mathrm{~F} / \mathrm{NI}$ & $\begin{array}{l}\text { Radiation recall dermatitis } \\
\text { or contact dermatitis }\end{array}$ & $\begin{array}{l}\text { Skin metastasis } \\
\text { from breast cancer }\end{array}$ & Chest & Misdiagnosis & Death from metastasis (2009) \\
\hline$\# 2$ & 2008 & $\mathrm{M} / \mathrm{NI}$ & Bacterial skin infection & $\begin{array}{l}\text { Squamous cell } \\
\text { carcinoma }\end{array}$ & Lower leg & $\begin{array}{l}\text { Delayed } \\
\text { diagnosis }\end{array}$ & Limb amputation (2009) \\
\hline$\# 3$ & 2007 & $\mathrm{~F} / 55$ & Melanocytic nevus & MM & $\begin{array}{l}\text { Left lateral } \\
\text { ankle }\end{array}$ & $\begin{array}{l}\text { Delayed } \\
\text { diagnosis }\end{array}$ & Death from metastasis (2010) \\
\hline$\# 4$ & 2009 & $\mathrm{M} / \mathrm{NI}$ & Oral melanocytic nevus & MM & Gingiva & Misdiagnosis & Death from metastasis (2014) \\
\hline$\# 5$ & 2009 & $\mathrm{M} / 32$ & Epithelioid hemangioma & MM & Gingiva & $\begin{array}{l}\text { Delayed } \\
\text { diagnosis }\end{array}$ & $\begin{array}{l}\text { Language disability } \\
\text { (mastication\&pronunciation) }\end{array}$ \\
\hline$\# 6$ & 2005 & $\mathrm{M} / 41$ & MM & MM & Forehead & $\begin{array}{l}\text { Performance } \\
\text { error }\end{array}$ & Death from metastasis (2007) \\
\hline$\# 7$ & 2005 & $\mathrm{M} / \mathrm{NI}$ & Cellulitis $\rightarrow$ panniculitis & $\begin{array}{l}\text { Peripheral T cell } \\
\text { lymphoma }\end{array}$ & Leg & $\begin{array}{l}\text { Delayed } \\
\text { diagnosis }\end{array}$ & $\begin{array}{l}\text { Hypogonadism with } \\
\text { azoospermia }\end{array}$ \\
\hline
\end{tabular}

F: female, M: male, NI: not identifiable, MM: malignant melanoma.

at the first instance; whereas 2 cases proceeded to the Appellate Court and 1 case to the Supreme Court. The average awarded amount was 42,553,644 $\pm 27,567,455$ Korean won (KRW, mean \pm standard deviation; range, $15,000,000 \sim 74,277,111 \mathrm{KRW})$; and the average amount claimed was $180,486,445 \pm 59,640,477$ KRW (range,
129,384,456 274,252,613 KRW) (Table 2).

\section{DISCUSSION}

This study analyzed a total of 7 medical malpractice lawsuits with regard to the skin cancer registered in the past 
Table 2. Summary of the judgments in the cases of the judicial precedents regarding the skin cancer (unit: Korean won)

\begin{tabular}{|c|c|c|c|c|c|c|c|c|}
\hline \multirow[b]{2}{*}{ Case } & \multirow[b]{2}{*}{$\begin{array}{c}\text { Year (clinical visit/ } \\
\text { start lawsuit/ } \\
\text { final sentence) }\end{array}$} & \multirow[b]{2}{*}{$\begin{array}{l}\text { Claimed } \\
\text { amounts }\end{array}$} & \multirow[b]{2}{*}{$\begin{array}{c}\text { Trial } \\
\text { outcome }\end{array}$} & \multirow[b]{2}{*}{$\begin{array}{l}\text { Awarded } \\
\text { amounts }\end{array}$} & \multicolumn{4}{|c|}{ Details of awarded amounts* } \\
\hline & & & & & $\begin{array}{c}\text { Lost earning } \\
\text { capacity } \\
\text { (disability rate, \%) }\end{array}$ & $\begin{array}{l}\text { Cost of treatment, } \\
\text { convalescent } \\
\text { care, etc. }\end{array}$ & $\begin{array}{l}\text { Limitation } \\
\text { of liability } \\
(\%)\end{array}$ & $\begin{array}{c}\text { Consolation } \\
\text { money }\end{array}$ \\
\hline$\# 1$ & $\begin{array}{l}\text { 2007/2010/2011 } \\
\text { (appellate court) }\end{array}$ & $129,384,456$ & $\begin{array}{l}\text { Partially award- } \\
\text { ed to plaintiff }\end{array}$ & $15,000,000$ & 0 & 0 & & $15,000,000$ \\
\hline$\# 2$ & 2008/2010/2011 & $141,742,662$ & $\begin{array}{l}\text { Settlement } \\
\text { decision }\end{array}$ & $70,000,000$ & & & & \\
\hline \#3 & 2007/2011/2012 & $158,754,989$ & $\begin{array}{l}\text { Partially award- } \\
\text { ed to plaintiff }\end{array}$ & $23,491,109$ & $\begin{array}{l}49,455,557 \\
\quad(100)\end{array}$ & $3,000,000$ & 20 & $13,000,000$ \\
\hline$\# 4$ & 2009/2015/2015 & $256,022,578$ & Dismissal & 0 & & & & \\
\hline \#5 & $\begin{array}{l}\text { 2009/2013/2017 } \\
\text { (appellate court) }\end{array}$ & $168,847,080$ & $\begin{array}{l}\text { Partially award- } \\
\text { ed to plaintiff }\end{array}$ & $74,277,111$ & $\begin{array}{c}254,365,837 \\
(30)\end{array}$ & $17,019,772$ & 20 & $20,000,000$ \\
\hline \#6 & $2005 / 2006 / 2008$ & $274,252,613$ & $\begin{array}{l}\text { Settlement } \\
\text { decision }\end{array}$ & $30,000,000$ & & & & \\
\hline \#7 & $\begin{array}{l}\text { 2005/2008/2013 } \\
\text { (supreme court) }\end{array}$ & $134,400,736$ & Dismissal & 0 & & & & \\
\hline
\end{tabular}

*Awarded amounts were calculated as followed: (lost earning capacity + cost of treatment, convalescent care, etc.) $\times$ limitation of liability + consolation money.

20 years $(1997 \sim 2017)$ in Korea. Except for 2 cases, the other 5 judicial cases were filed since 2010. Increasing pattern of the malpractice claims since 2010 was also reported in another study related to the plastic surgery ${ }^{3}$. The course of the skin cancer involves a long time from the diagnosis to the fatal outcome. This study revealed that, for a skin cancer to attain the final outcome, several years elapsed ranging from at least 2 years to the maximum 5 years. Literature reports in Korea have reported a steady increase in the skin cancer incidence in Korea ${ }^{7-9}$. Considering this, the skin cancer related lawsuits are likely to increase in the near future.

Every doctor, including a dentist, needs to know about the skin findings suspected of malignancy, and should keep in mind the possibility of developing skin cancer. Skin cancers, such as MM and SCC, are common in skin areas exposed to ultraviolet rays, but may also occur in the oral cavity or gum ${ }^{12,13}$. Metastatic skin cancer can manifest at various sites of the body according to the type of the cancer of primary origin ${ }^{14}$. Cutaneous lymphoma may involve multiple systemic symptoms with skin involvement at various sites ${ }^{15}$. In this study, a majority of cases were related to the MM. In a study of analysis of 99 litigation cases related to the skin cancer, BCC $(n=25), M M(n=24)$, and SCC $(n=20)$ were the most common ${ }^{16}$.

The medical disputes regarding the skin cancer can occur at various stages of the treatment course ${ }^{17}$. It can be divided into 3 main steps: 1) when a patient meets a physician in the examination room, and a differential diagnosis
Table 3. Plaintiff's allegation and the medical disputes listed in each case-related judgment

\begin{tabular}{|c|c|c|c|c|c|}
\hline \multirow[b]{2}{*}{ Case } & \multirow[b]{2}{*}{$\begin{array}{l}\text { Misdi- } \\
\text { agnosis }\end{array}$} & \multicolumn{2}{|c|}{ Delayed diagnosis } & \multirow[b]{2}{*}{$\begin{array}{l}\text { Perfor- } \\
\text { mance } \\
\text { error }\end{array}$} & \multirow[b]{2}{*}{$\begin{array}{l}\text { Lack of } \\
\text { informeo } \\
\text { consent }\end{array}$} \\
\hline & & $\begin{array}{l}\text { Not/delayed } \\
\text { check the } \\
\text { pathology report }\end{array}$ & $\begin{array}{c}\text { Pathology } \\
\text { interpretation } \\
\text { error }\end{array}$ & & \\
\hline$\# 1$ & $\bigcirc$ & & & & \\
\hline \#2 & & $\mathrm{D}$ & & & \\
\hline \#3 & & 0 & & & \\
\hline \#4 & $x$ & & & & $x$ \\
\hline \#5 & & & $\bigcirc^{*}$ & $x$ & $x$ \\
\hline \#6 & & & & D & $\mathrm{D}$ \\
\hline \#7 & & & $x$ & & $x$ \\
\hline
\end{tabular}

$\bigcirc$ : in favor of the plaintiff, $D$ : settlement decision, $x$ : dismissal for claim. ${ }^{*} \mathrm{CD} 31$ was mis-interpreted as positive in the primary histologic examination.

is made (misdiagnosis), 2) when the final diagnosis is confirmed by the clinicians or pathologists (delayed diagnosis), 3) when a clinician decides the method of treatment, and treats the patient based on the final diagnosis (performance error). These steps involve the physicians of any specialty, who may become the subjects of medical litigation, including dermatologists ${ }^{18}$. Furthermore, informed consent should be obtained from the patients in all treatment courses. Table 3 summarizes the alleged violation of duty and the admitted fault (type of negligence/ malpractice) by the court for each case in the present study. 
In the first step, medical staff is likely to perform a medical error most commonly. Lydiatt ${ }^{16}$ reported that more than half of the 99 skin cancer-related lawsuits (54\%) occurred due to the diagnostic error for the skin cancer, and about half of them $(48 \%)$ were not confirmed by biopsy. Jackson ${ }^{18}$ reported that in 75 melanoma-related malpractice cases, the medical error of delay in making diagnosis was mostly common $(29 \%)$. Case \#1 of this study involved the delayed biopsy caused by misdiagnosis; whereas, case \#4 was related to the misdiagnosis of the skin cancer, which led to the medical litigation. It is necessary to perform a prompt skin biopsy if there are suspected findings.

The second step involves a diagnostic error even after an initial diagnosis. There may be late checking of the pathologic result following a histopathologic diagnosis. The cases \#2 and \#3 showed pitfalls in checking the pathologic reports. In case \#3, the histopathologic findings of the skin cancer were found in the third biopsy specimen, but the medical staff did not confirm the results. One study in Korea reported that in $3 \%$ of the cases, the patients did not visit the hospital after the biopsy for checking the result, many of which included findings of malignancy ${ }^{19}$. As a plan of prevention, it is necessary to make an automated notification system and deliver the abnormal findings such as malignant tumors to the medical staff or patients ${ }^{19,20}$.

Physicians should consider the possibility of interpretation error while specimen processing ${ }^{16,18}$. Crowson $^{21}$ found 25 significant errors in a retrospective study of the pathologic results of 35,765 cases. In this study, a medical pitfall of the pathology department was noted in case \#5, resulting in the judgement in favor of the plaintiff. The errors in the histopathological diagnosis of the MM mentioned in the court rulings sentence were considered in the method of staining and interpretation. To prevent a pathologist's error of interpretation, it is necessary to make the diagnosis in cooperation with a clinician or by obtaining a second opinion from another pathologist in cases with unclear pathologic results ${ }^{22}$.

There can also be medical disputes in the third step; the so-called performance error. In skin cancer patients, recurrence should always be searched for by regular follow-ups. The clinicians should keep newly updated guidelines in mind and consider additional diagnostic plan for metastasis $^{23}$. In case \#6, the main disputed pitfall was the failure in performing the regular follow-up observation.

It is important to obtain an informed consent from the patients at all steps of the medical practice. The current Medical Service Act (Article 24-2, https://elaw.klri.re.kr/kor_ service/lawView.do?hseq $=40970$ \&lang $=\mathrm{ENG}$ ) specifically stipulates the obligation of the medical staff to explain the patients the possible risks involved in cases of invasive procedures. However, in addition to the means of avoiding legal liability by the medical practitioners themselves, an informed consent is also necessary to ensure the patient's right to self-determination ${ }^{24}$. The judicial precedents showed that misdiagnosis does not always mean malpractice. The court decision in the precedent case \#4 was that there was no fault of the medical staff. The reason for the court rulings was that, the dentist had no obligation to perform the diagnostic studies for the nevus without the suspected symptoms of the MM during the implant procedure. In the precedent case \#7 also, the negligence for delayed diagnosis in the patient with ambiguous physical or laboratory findings involving cutaneous lymphoma was not admitted. Peripheral T cell lymphoma was diagnosed based on the World Health Organization classification system along with clinical and laboratory information. Some cases are difficult to diagnose correctly ${ }^{25}$. In this regard, the judge sentenced that the patient being younger and without nodal involvement or any typical laboratory result, it was difficult to diagnose peripheral $\mathrm{T}$ cell lymphoma. If the medical disputes occur despite the best care, the physician should give prima facie evidence of the reason to the judge, and it will help the judge to make the correct decision.

In the cases with the judgments in favor of the plaintiffs, the court limited the defendants' liability for several reasons that affected the deterioration progress and diagnosis of the skin cancer. First reason involved the characteristics of the disease itself as a major cause of liability limitation. Especially in the cases involving the MM, the court noted the characteristics of poor malignancy and diagnostic difficulties of the MM itself. Moreover, since the 5-year survival rate was low in the state of advanced cancer, the limitation of liability by the court rulings included the difficulty to estimate the duration of treatment or avoid extensive resection of cancerous lesions, even though the prompt diagnosis and treatment were noted. Second, the factor of patient was also the reason for the limitation of liability, involving the deterioration of disease course. Not attending the follow-up for further medical examination for a certain period despite the change of symptoms is a factor of liability limitation related to the patients.

This study had some limitations. First, information on medical records could not be verified because, this study was based on the limited clinical information provided in the official copies of the written judgments. In addition, 7 litigated cases are not sufficient in representing all the medical disputes related to the skin cancer. This suggests that it is necessary to research on the disputes other than the lawsuits, such as registered with the Korea Medical Dispute Meditation and Arbitration Agency. Furthermore, 
a future analysis of the new judicial precedents of skin cancer will be needed. However, this study is meaningful in that it is the first paper to systematically analyze the medical disputes related to the skin cancer in Korea by identifying and analyzing all the litigation cases related to the skin cancer in Korea.

In conclusion, the incidence of skin cancer is increasing, and it is expected to lead to more medical malpractice claims in future. Analysis of judicial decision can be helpful to prevent medical malpractices and reduce legal risk for physicians. In order to prevent medical malpractices, a physician should make prompt diagnosis or treatment plans based on appropriate interpretation of the clinical or laboratory results. In all courses of medical practice, informed consent should be obtained with detailed explanation to the patients.

\section{CONFLICTS OF INTEREST}

The authors have nothing to disclose.

\section{ORCID}

Su Hwan Shin, https://orcid.org/0000-0002-2812-1985

Won Lee, https://orcid.org/0000-0002-6948-6948

So Yoon Kim, https://orcid.org/0000-0001-7015-357X

Gwanghyun Jo, https://orcid.org/0000-0003-0580-2312

Je-Ho Mun, https://orcid.org/0000-0002-0734-2850

Soo Ick Cho, https://orcid.org/0000-0003-3414-9869

\section{REFERENCES}

1. Patterson DC, Grelsamer R, Bronson MJ, Moucha CS. Lawsuits after primary and revision total knee arthroplasty: a malpractice claims analysis. J Am Acad Orthop Surg 2017; 25:e235-e242.

2. Zengerink I, Reijman M, Mathijssen NM, Eikens-Jansen MP, Bos PK. Hip arthroplasty malpractice claims in the Netherlands: closed claim study 2000-2012. J Arthroplasty 2016; 31:1890-1893.e4.

3. Park BY, Kwon JW, Kang SR, Hong SE. Analysis of malpractice claims associated with surgical site infection in the field of plastic surgery. J Korean Med Sci 2016;31:19631968.

4. Shin SH, Kim SY, Jang SG, Lee W. Analysis of closed medical litigation in urology. Investig Clin Urol 2017;58: 317-323.

5. Lee KS, Shim JJ, Shim JH, Oh JS, Yoon SM. Cerebral aneurysms in judicial precedents. J Korean Neurosurg Soc 2018; 61:474-477.

6. Shin S, Jang SG, Min K, Lee W, Kim SY. The legal doctrine on the liability of physicians in medical malpractice lawsuits involving complex regional pain syndrome. J Korean
Med Sci 2018;33:e46.

7. Lee K, Kim MJ, Chae SY, Cha HW, Jang YH, Lee WJ, et al. A clinical study of cutaneous malignant tumors in Daegu city and Kyungpook province for the recent 20 years: comparison of the first (1994 2003) and second decade (2004 2013). Korean J Dermatol 2015;53:505-514.

8. Oh $\mathrm{CM}$, Cho H, Won YJ, Kong HJ, Roh $\mathrm{YH}$, Jeong $\mathrm{KH}$, et al. Nationwide trends in the incidence of melanoma and nonmelanoma skin cancers from 1999 to 2014 in South Korea. Cancer Res Treat 2018;50:729-737.

9. Kim HS, Cho EA, Bae JM, Yu DS, Oh ST, Kang H, et al. Recent trend in the incidence of premalignant and malignant skin lesions in Korea between 1991 and 2006. J Korean Med Sci 2010;25:924-929.

10. Mun JH, Ohn J, Kim WI, Park SM, Kim MB. Dermoscopy of melanomas on the trunk and extremities in Asians. PLoS One 2016;11:e0158374.

11. Wu KH, Yen YL, Wu CH, Hwang CY, Cheng SY. Learning from an analysis of closed malpractice litigation involving myocardial infarction. J Forensic Leg Med 2017;48:41-45.

12. Massano J, Regateiro FS, Januário G, Ferreira A. Oral squamous cell carcinoma: review of prognostic and predictive factors. Oral Surg Oral Med Oral Pathol Oral Radiol Endod 2006;102:67-76.

13. Kim HS, Kim EK, Jun HJ, Oh SY, Park KW, Lim DH, et al. Noncutaneous malignant melanoma: a prognostic model from a retrospective multicenter study. BMC Cancer 2010; 10:167.

14. Schulman JM, Pauli ML, Neuhaus IM, Sanchez Rodriguez R, Taravati K, Shin US, et al. The distribution of cutaneous metastases correlates with local immunologic milieu. J Am Acad Dermatol 2016;74:470-476.

15. Lee MW, Korean Dermatopathology Research Group. Characteristics of cutaneous lymphomas in Korea. Clin Exp Dermatol 2003;28:639-646.

16. Lydiatt DD. Medical malpractice and cancer of the skin. Am J Surg 2004;187:688-694.

17. Lehmann L, Wesselmann U, Weber B, Smentkowski U. Medical error analysis in dermatology according to the reports of the North Rhine Medical Association from 20042013. J Dtsch Dermatol Ges 2015;13:903-908.

18. Jackson R. Malignant melanoma: a review of 75 malpractice cases. Int J Dermatol 1997;36:497-498.

19. Lim JS, Yoon HS, Cho S, Park HS. The delivery rates of pathology test results to patients: a single-center experience in a secondary referral center. Ann Dermatol 2017;29:307313.

20. Piva E, Sciacovelli L, Zaninotto M, Laposata M, Plebani M. Evaluation of effectiveness of a computerized notification system for reporting critical values. Am J Clin Pathol 2009; 131:432-441.

21. Crowson AN. Medicolegal aspects of neoplastic dermatology. Mod Pathol 2006;19 Suppl 2:S148-S154.

22. Geller BM, Frederick PD, Knezevich SR, Lott JP, Nelson HD, Titus LJ, et al. Pathologists' use of second opinions in interpretation of melanocytic cutaneous lesions: policies, practices, and perceptions. Dermatol Surg 2018;44:177-185. 
23. Sondak VK, Messina JL, Zager JS. Selecting patients with thin melanoma for sentinel lymph node biopsy-this time it's personal. JAMA Dermatol 2017;153:857-858.

24. Park BY, Kwon J, Kang SR, Hong SE. Informed consent as a litigation strategy in the field of aesthetic surgery: an analysis based on court precedents. Arch Plast Surg 2016;43:
402-410.

25. Bellei M, Sabattini E, Pesce EA, Ko YH, Kim WS, Cabrera $M E$, et al. Pitfalls and major issues in the histologic diagnosis of peripheral T-cell lymphomas: results of the central review of 573 cases from the T-Cell Project, an international, cooperative study. Hematol Oncol 2017;35:630-636. 